\title{
Perencanaan Pengelolaan Sampah Di Pasar Dasan Agung Kota Mataram Dengan Pendekatan Reduce, Reuse Dan Recycle (3R)
}

\author{
Wahyudin $^{1^{*}}$, Fitriah $^{2}$, Azwaruddin $^{3}$ \\ ${ }^{1,2,3}$ Program Studi Teknik Lingkungan, Sekolah Tinggi Teknik Lingkungan (STTL) Mataram \\ Jl. Bung Karno No. 60 Pagesangan Timur, Kecamatan Mataram, Kota Mataram, NTB, 83127 \\ *Koresponden email: wahyudin.mts@gmail.com
}

Diterima: 14 Maret 2020

Disetujui: 1 April 2020

\begin{abstract}
Waste management in the Dasan Agung Market in Mataram City still uses conventional patterns. This pattern is not in line with the NTB Province policy that launched the concept of zero waste in 2019-2023. One approach that can support the program is the $3 \mathrm{R}$ method of waste management. This study aims to develop a waste management plan using the $3 \mathrm{R}$ approach. The method used in this study is the observation method, which is observing the current conditions and measuring the generation and composition of waste. The technique of determining the sample and measurement time and the procedure refers to SNI-19-3964-1995. The results showed that the amount of solid waste generation in Dasan Agung Market was $2.7 \mathrm{~m}^{3}$ / day and the weight of solid waste was $467 \mathrm{~kg}$ / day. Waste composition was obtained by organic waste $52.60 \%$ and inorganic waste $47.40 \%$. TPS 3R is planned with an area of 110 $\mathrm{m}^{2}$, namely $74 \mathrm{~m}^{2}$ for composting area and $36 \mathrm{~m}^{2}$ for sorting and handling inorganic waste, and residual waste. The composting system implemented is using the drum method with a capacity of 100 liters, a total of 307 pieces. Waste Management Planning using the 3R Approach is capable of handling 80\% of the waste, and $20 \%$ of the residue is disposed of in the landfill.
\end{abstract}

Keywords: Mataram City, Traditional Market, Waste Market, Solid Waste Management, TPS 3R.

\begin{abstract}
Abstrak
Pengelolaan sampah di Pasar Dasan Agung Kota Mataram masih menggunakan pola konvensional. Pola tersebut tidak sejalan dengan kebijakan Provinsi NTB yang mencanangkan konsep zero waste pada Tahun 2019-2023. Salah satu pendekatan yang dapat mendukung program tersebut adalah dengan konsep pengelolaan sampah metode 3R. Penelitian ini bertujuan untuk menyusun perencanaan pengelolaan sampah dengan pendekatan 3R. Metode yang digunakan dalam penelitian ini dengan metode observasi, yaitu pengamatan kondisi saat ini dan mengukur timbulan dan komposisi sampah. Teknik penentuan sampel dan waktu pengukuran serta tata caranya mengacu pada SNI-19-3964-1995. Hasil penelitian menunjukkan bahwa besaran timbulan sampah di Pasar Dasan Agung sejumlah $2,7 \mathrm{~m}^{3} / \mathrm{hari}$ dan berat timbulan sampah sebanyak $467 \mathrm{~kg} /$ hari. Komposisi sampah diperoleh sampah organik $52,60 \%$ dan sampah anorganik 47,40\%. TPS 3R direncanakan dengan luas lahan $110 \mathrm{~m}^{2}$, yakni $74 \mathrm{~m}^{2}$ untuk area komposting dan $36 \mathrm{~m}^{2}$ untuk kegiatan pemilahan dan penanganan sampah anorganik, serta sampah residu. Sistem pengomposan yang diterapkan adalah menggunakan metode drum kapasitas 100 liter, sejumlah 307 buah. Perencanaan Pengelolaan Sampah dengan Pendekatan 3R, mampu menangani sampah sebesar $80 \%$ sampah, dan residunya $20 \%$ dibuang ke TPA.
\end{abstract}

Kata Kunci: Kota Mataram, Pasar Tradisional, Sampah Pasar, Pengelolaan sampah, TPS 3R.

\section{Pendahuluan}

Pasar adalah salah satu fasilitas kota sebagai tempat transaksi jual beli antara penjual dan pembeli. Dalam aktivitasnya, diperlukan adanya fasilitas penunjang seperti kios-kios atau tempat jualan, penerangan, air bersih, sarana kebersihan dan sebagainya. Pasar tradisional berfungsi untuk menyediakan kebutuhan harian masyarakat seperti sayur mayur, ikan, daging, barang pecah belah dan lain lain. Pasar tradisional terdapat mulai dari kota besar hingga di pedesaan [1].

Hasil lain dari aktivitas perdagangan di pasar adalah adanya sampah dari masing-masing kegiatan, sampah tersebut semakin hari semakin bertambah seiring dengan perkembangan pasar dan aktivitas dalam pasar itu sendiri. Undang-undang No. 18 Tahun 2008 tentang Pengelolaan Sampah, menyebutkan sampah adalah sisa kegiatan sehari-hari manusia atau proses alam yang berbentuk padat [2]. Buangan padat yang dimaksud adalah berupa zat organik dan anorganik yaitu bersifat dapat terurai dan tidak dapat 
terurai. Apabila sampah tidak dikelola dengan baik, maka dapat menimbulkan dampak yang besar terhadap kesehatan dan lingkungan. Pengaruhnya terhadap kesehatan bisa secara langsung maupun tidak langsung. Pengaruh langsung disebabkan karena adanya kontak langsung antara manusia dengan sampah tersebut. Sedangkan pengaruh tidak langsung umumnya disebabkan oleh adanya vektor yang membawa kuman penyakit yang berkembangbiak di dalam sampah kepada manusia dan pengaruh terhadap lingkungan apabila pengelolaan sampah yang kurang baik dapat mengganggu estetika lingkungan dan menimbulkan bau yang kurang sedap [3]. Tingkat pencemaran berawal dari munculnya pembuangan sampah disembarang tempat atau di TPS ilegal. Di wilayah Kecamatan Mataram Kota Mataram, TPS Ilegal sebagian besar berada sekitar 15 meter dari sungai yaitu sebesar 60,46\% dan sisanya berada di lahan kosong [4].

Salah satu pendekatan penanganan buangan padat atau sampah adalah melalui metode $3 \mathrm{R}$ (reduce, reuse, dan recycle) sejak dari sumber sampah sebelum diangkut ke tempat pemrosesan akhir sampah (TPA) [5]. Oleh karena itu, pengelolaan sampah baik di lingkup kota atau unit-unit kegiatan, diperlukan perencanaan pengelolaan sampah yang terpadu. Perencanaan pengelolaan sampah di suatu wilayah diperlukan data timbulan, komposisi, dan karakteristik sampah sebagai dasar penentuan konsep pengelolaan sampah dan tingkat kebutuhan sarana dan prasaran persampahan pendukung pengelolaan sampah seperti teknologi pengolahan yang digunakan [6]. Besarnya timbulan sampah yang tidak dikelola dengan baik melalui sistem pengelolaan sampah perkotaan terpadu dapat menyebabkan berbagai masalah pencemaran lingkungan, akhirnya berdampak pada kerusakan lingkungan dan kesehatan masyarakat. Selain mencegah pencemaran lingkungan, pengelolaan sampah juga dapat menjadi berkah bagi manusia, dimana dengan pengelolaan sampah yang baik melalui konsep 3R dapat memberikan penghasilan dan keuntungan bagi masyarakat [7].

Komposisi sampah pasar masih didominasi oleh sampah organik 52,63\% dan sampah anorganik sebesar 47,37\% [8]. Besarnya komposisi sampah khususnya sampah organik tersebut, apabila tidak ditangani dengan baik, dapat menimbulkan pencemaran lingkungan terutama masalah bau. Penanganan sampah dengan metode $3 \mathrm{R}$ dipandang mampu menyelesaikan masalah persampahan melalui metode pengurangan sampah, penggunaan kembali dan daur ulang sampah. Dengan demikian, masalah pencemaran lingkungan seperti bau dan lainnya, dapat teratasi. Selain itu, metode $3 \mathrm{R}$ ini menerapkan tingkat pelayanan $100 \%$, sistem pewadahan terpilah, pengumpulan dan pengangkutan sampah berdasarkan jenis sampah, dan pengolahan sampah [9].

Pasar Dasan Agung merupakan salah satu pasar tradisional di wilayah Kota Mataram dengan pasar tipe A, luas area $2.296 \mathrm{~m}^{2}$ dan luas bangunan $1.505 \mathrm{~m}^{2}$, dan jumlah pedagang sebanyak 405 pedagang, dengan komoditi sembako, sayur-mayur, rempah-rempah dan buah-buahan [10]. Berdasarkan hasil survei pendahuluan, Pasar Dasan Agung memiliki tata letak ruangan yang teratur dan tingkat kelayakan gedungnya masih cukup bagus untuk dimanfaatkan. Bidang kebersihan, Pasar Dasan Agung memiliki fasilitas TPS berupa kontainer sebanyak 2 unit yang ditempatkan di depan gedung pasar. Sedangkan jenis pewadahan yang digunakan adalah sebagian besar menggunakan plastik kresek, keranjang anyaman bambu, dan karung. Jenis pewadahan yang digunakan tersebut, bisa dikatakan tidak memenuhi syarat pewadahan yang baik seperti harus kedap air, tidak mudah berkarat, kuat, tertutup dan mudah dibersihkan. Masalah lain yang dijumpai adalah masih berserakannya sampah di sekitar TPS dan belum adanya pengolahan sampah pengolahan sampah. Kondisi tersebut menggambarkan kondisi pengelolaan sampah di Pasar Dasan Agung masih dibawah standar.

Untuk menangani permasalahan sampah di Pasar Dasan Agung Kota Mataram, perlu dikembangkan pengelolaan sampah secara mandiri oleh pengelola pasar melalui pendekatan pengelolaan sampah 3R. Perencanaan pengelolaan sampah dengan pendekatan 3R di Pasar Dasan Agung diharapkan dapat memenuhi target Pemerintah Provinsi NTB menuju "NTB Zero Waste" pada tahun 2023 dan dapat menciptakan lingkungan pasar yang bersih dan indah.

\section{Metode Penelitian}

Penelitian ini dilaksanakan di Pasar Dasan Agung Kota Mataram dimulai dengan pengukuran timbulan dan komposisi sampah yang mengacu pada SNI 19-3964-1994 [11]. Hasil pengukuran contoh timbulan dan komposisi sampah di lokasi penelitian, kemudian dilanjutkan dengan beberapa analisis, seperti analisis timbulan sampah, komposisi sampah dan densitas sampah. Analisis lain yang dilakukan adalah analisis sistem pengelolaan sampah di Pasar Dasan Agung, meliputi sistem pewadahan, sistem pengumpulan dan pengangkutan, dan analisis tingkat kebutuhan sarana dan prasarana pengelolaan sampah 3R di Pasar Dasan Agung. 


\section{Hasil dan Pembahasan}

\section{Gambaran Umum Pasar Dasan Agung}

Pasar Dasan Agung merupakan pasar rakyat terbesar di wilayah kecamatan Selaparang yang berada tepat di sebelah utara kompleks Islamic Center Nusa Tenggara Barat. Pasar dengan status tipe A ini beralamat di Jalan Aneka, Kelurahan Dasan Agung, Kecamatan Selaparang, Kota Mataram. Pasar Dasan Agung terakhir mengalami perbaikan pada tahun 2006 dan kondisi bangunan pada saat ini masih tergolong baik.

Pasar Dasan Agung memiliki luas lahan $2.296 \mathrm{~m}^{2}$ dan luas bangunan 1183,5 $\mathrm{m}^{2}$ dengan jumlah pedagang 405 orang, Kios yang dimiliki sejumlah 46 unit dan Los sejumlah 5 unit. Komoditas yang diperdagangkan sehari-hari antara lain sembako, sayur, rempah-rempah, buah-buahan, lauk pauk, kuliner dan konveksi [10].

\section{Gambaran Umum Pengelolaan Sampah Pasar Dasan Agung}

Pasar Dasan Agung di kelola oleh Dinas Perdagangan Kota Mataram. Unit Pengelola Teknis (UPT) Pasar Dasan Agung bertugas mengelola lingkungan pasar meliputi kebersihan, penarikan retribusi, dan lainnya. Pengelola pasar bagian kebersihan memiliki pegawai sebanyak 5 orang tugasnya adalah untuk membersihakan lingkungan pasar, meliputi kegiatan penyapuan, pengumpulan sampah di setiap pedagang dan diangkut ke TPS kontainer yang disediakan di dalam wilayah pasar. Pengangkutan sampah dari kontainer, menjadi tugas Dinas kebersihan Kota Mataram untuk dibawa ke TPA Kobon Kongok Lombok Barat. Frekuensi pengumpulan sampah yang dikerjakan oleh petugas kebersihan pasar sebanyak 2 kali sehari yaitu pada pagi dan sore hari.

Sistem pengelolaan sampah Pasar Dasan Agung yang diterapkan, antara lain sebagai berikut:

1) Timbulan, Komposisi dan Densitas Sampah

a) Timbulan Sampah

Pengukuran dan perhitungan timbulan sampah di Pasar Dasan Agung berdasarkan SNI 193964-1995 [11] dengan menggunakan 10 contoh sampel pedagang dapat dikelompokkan menjadi dua jenis timbulan sampah, yaitu volume timbulan sampah dan berat timbulan sampah. Hasil pengukuran volume timbulan sampah dapat dilihat pada Tabel 1.

Tabel 1. Volume timbulan sampah di Pasar Dasan Agung

\begin{tabular}{rlrrrr}
\hline \multirow{2}{*}{ No. Sampel } & & \multicolumn{3}{c}{ Volume Sampah (Liter) } & \multirow{2}{*}{ Rata-rata } \\
\cline { 3 - 4 } & & Hari I & Hari II & Hari III & \\
\hline 1. & Sampel 1 & 7 & 7,5 & 7 & 7,17 \\
2. & Sampel 2 & 10 & 12 & 11,5 & 11,17 \\
3. & Sampel 3 & 10 & 10,3 & 10,1 & 10,13 \\
4. & Sampel 4 & 8 & 8 & 8 & 8,00 \\
5. & Sampel 5 & 7,5 & 7 & 7,2 & 7,23 \\
6. & Sampel 6 & 5 & 6 & 5,6 & 5,53 \\
7. & Sampel 7 & 5 & 4,5 & 4,8 & 4,77 \\
8. & Sampel 8 & 4 & 3,5 & 3,8 & 3,77 \\
9. & Sampel 9 & 4 & 4,5 & 5,5 & 4,67 \\
10. & Sampel 10 & 4 & 4 & 5 & 4,33 \\
\hline & & & & & 6,68 \\
\hline
\end{tabular}

Sumber: Hasil analisa, 2019 
Volume Timbulan Sampah

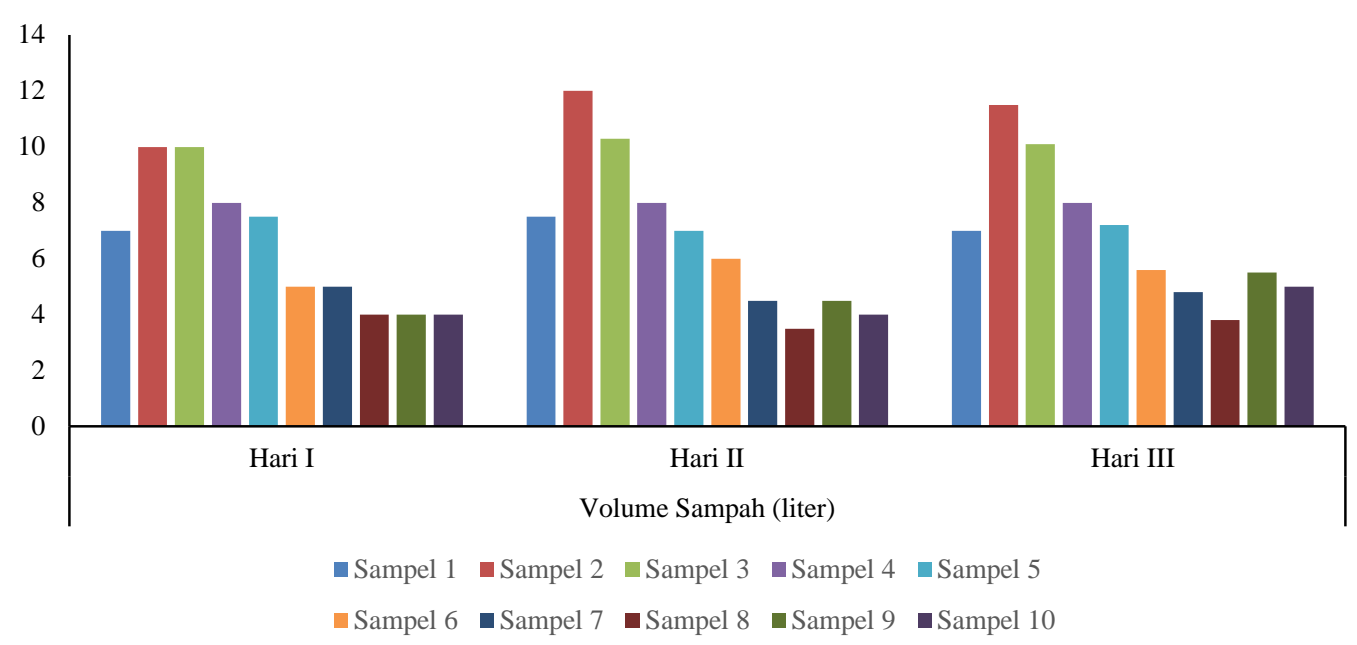

Gambar 1. Grafik volume timbulan sampah di Pasar Dasan Agung

Berdasarkan Tabel 1 dapat diketahui volume timbulan sampah di Pasar Dasan Agung yaitu sebanyak 6,68 liter/pedagang/hari. Dengan mengetahui data volume timbulan sampah per pedagang, maka dapat dihitung total volume timbulan sampah yang dihasilkan oleh semua pedagang di Pasar Dasan Agung. Data tersebut dapat digunakan sebagai dasar perencanaan pengelolaan sampah.

Selain volume timbulan sampah, berat sampah juga dapat dihasilkan dari pelaksanaan pengukuran timbulan sampah di Pasar Dasan Agung. Hasil pengukuran berat timbulan sampah dapat dilihat pada Tabel 2.

Tabel 2. Berat Timbulan Sampah di Pasar Dasan Agung

\begin{tabular}{|c|c|c|c|c|c|}
\hline \multirow{2}{*}{ No. } & \multirow{2}{*}{ Sampel } & \multicolumn{3}{|c|}{ Berat Sampah $(\mathrm{Kg})$} & \multirow{2}{*}{ Rata-rata } \\
\hline & & Hari I & Hari II & Hari III & \\
\hline 1. & Sampel 1 & 1,2 & 1,6 & 1,3 & 1,37 \\
\hline 2. & Sampel 2 & 2,3 & 2,5 & 2,2 & 2,33 \\
\hline 3. & Sampel 3 & 1,8 & 1,9 & 1,8 & 1,83 \\
\hline 4. & Sampel 4 & 1,6 & 1,5 & 1,6 & 1,57 \\
\hline 5. & Sampel 5 & 0,8 & 0,9 & 0,6 & 0,77 \\
\hline 6. & Sampel 6 & 0,4 & 0,9 & 1,2 & 0,83 \\
\hline 7. & Sampel 7 & 0,7 & 0,6 & 1 & 0,77 \\
\hline 8. & Sampel 8 & 0,3 & 0,7 & 1,3 & 0,77 \\
\hline 9. & Sampel 9 & 0,4 & 0,5 & 0,8 & 0,57 \\
\hline 10. & Sampel 10 & 0,5 & 1 & 0,7 & 0,73 \\
\hline \multicolumn{5}{|c|}{ Rata-rata } & 1,15 \\
\hline
\end{tabular}

Sumber: Hasil analisa, 2019 


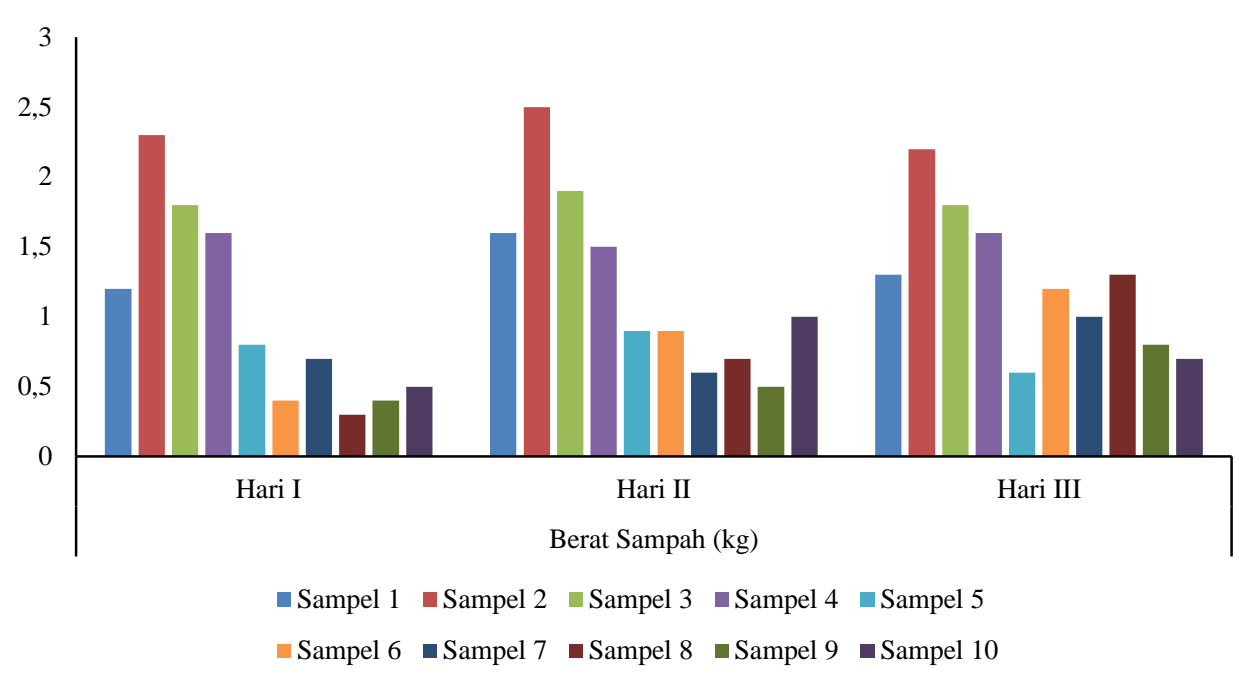

Gambar 2. Grafik berat timbulan sampah di Pasar Dasan Agung

Berdasarkan Tabel 2, dapat diketahui berat timbulan sampah di Pasar Dasan Agung yaitu sebanyak $1,15 \mathrm{~kg} /$ pedagang/hari. Dengan mengetahui data berat timbulan sampah per pedagang, maka dapat dihitung total berat timbulan sampah yang dihasilkan oleh semua pedagang di Pasar Dasan Agung berdasarkan jumlah pedagang yang ada di pasar tersebut.

b) Komposisi Sampah

Berdasarkan hasil pengukuran timbulan sampah di lokasi penelitian, dimana sampah setelah dilakukan pemilahan maka dilanjutkan dengan pengukuran berat dan volume sampah berdasarkan jenis sampah, yaitu sampah organik dan organik. Adapun hasil pengukuran komposisi sampah yang dihasilkan seperti ditunjukkan pada Tabel 3 berikut ini.

Tabel 3. Komposisi sampah di Pasar Dasan Agung

\begin{tabular}{lcc}
\hline \multicolumn{1}{c}{ Jenis Sampah } & $\begin{array}{c}\text { Komposisi Berat } \\
(\%)\end{array}$ & $\begin{array}{c}\text { Komposisi Volume } \\
(\%)\end{array}$ \\
\hline Organik & 52,60 & 54,27 \\
Anorganik & 47,40 & 45,73 \\
\hline Jumlah & 100,00 & 100,00 \\
\hline Sumber: Hasil analisa, 2019 & &
\end{tabular}

Komposisi sampah yang ditunjukkan pada Tabel 3 merupakan komposisi sampah menurut volume sampah, dimana jenis sampah dikelompokkan dalam dua jenis sampah, yaitu sampah organik dan anorganik. Hasil pengukuran menunjukkan bahwa komposisi sampah organik lebih dominan dari pada sampah anorganik yaitu sampah organik sebanyak 54,27\% sedangkan sampah anorganik sebanyak 45,73\%.

Komposisi lain yang diukur adalah sampah berdasarkan satuan berat sampah. Dimana sampah organik masih menjadi jenis sampah yang dominan yang ada di Pasar Dasan Agung, yakni sampah organik sebesar 52,60\% dan sampah anorganik sebesar 47,40\%.

c) Densitas Sampah

Densitas adalah satuan berat dibagi volume $\left(\mathrm{kg} / \mathrm{m}^{3}\right)$. Perhitungan densitas sampah, menggunakan data hasil pengukuran timbulan sampah yang mengacu pada SNI 19-39641994 [11], baik berupa berat timbulan sampah $(\mathrm{kg})$, maupun volume timbulan sampah $\left(\mathrm{m}^{3}\right)$. Hasil pembagian data timbulan berat dan volume sampah maka diperoleh data densitas sampah $\left(\mathrm{kg} / \mathrm{m}^{3}\right)$.

Data densitas sampah diperoleh dari hasil pengukuran timbulan dan komposisi sampah. Data diperoleh dari kotak ukur berukuran $40 \mathrm{~cm}$ x $15 \mathrm{~cm}$ x $20 \mathrm{~cm}$. Sampah yang diukur adalah sampah dari satu sampel per hari. Dari data densitas tersebut dilakukan analisis data untuk mengetahui rata-rata densitas sampah di Pasar Dasan Agung per hari. Densitas sampah di Pasar Dasan Agung dapat dilihat pada Tabel 4 berikut: 
Tabel 4. Densitas sampah di Pasar Dasan Agung

\begin{tabular}{crrr}
\hline Hari & Berat $(\mathrm{Kg})$ & Volume $\left(\mathrm{m}^{3}\right)$ & Densitas $\left(\mathrm{Kg} / \mathrm{m}^{3}\right)$ \\
\hline I & 1,2 & 0,007 & 171,43 \\
II & 1,6 & 0,0075 & 213,33 \\
III & 1,3 & 0,007 & 185,71 \\
\hline \multicolumn{3}{c}{ Jumlah } & 570,48 \\
\hline \multicolumn{3}{c}{ Rata-rata }
\end{tabular}

Sumber: Hasil analisa, 2019

Rata-rata densitas timbulan sampah di Pasar Dasan Agung adalah sebesar 190,16 Kg/m . Dari hasil rata-rata densitas timbulan sampah di Pasar Dasan Agung ini dapat dilihat berapa luas lahan yang diperlukan untuk membangun TPS 3R di Pasar Dasan Agung.

2) Pewadahan

Pewadahan merupakan tempat penyimpanan sampah yang disediakan oleh masing-masing pedagang pada kios atau tempat dagangannya. Para pedagang membuang sampahnya di pewadahan yang disiapkan masing-masing sebelum dikumpulkan dan dibuang oleh petugas kebersihan pasar. Jenis pewadahan yang digunakan di Pasar Dasan agung berupa keranjang anyaman bambu, plastik kresek, dan karung. Jenis pewadahan yang digunakan tersebut tidak memenuhi standar pewadahan yang baik yaitu kedap air, tertutup, dan terpilah sesuai jenis sampah [12].

3) Pengumpulan

Kegiatan pengumpulan sampah dari sumber sampah (pedagang) dikerjakan oleh petugas kebersihan pasar yang berjumlah 5 orang. Pengumpulan sampah dilakukan setiap hari dengan banyak frekuensi pengumpulan sebanyak satu kali yaitu pada pukul 13.00 Wita. Kegiatan pengumpulan menggunakan gerobak sampah dengan kapasitas $0,5 \mathrm{~m}^{3}$ sebanyak 2 unit. Sampah yang dikumpulkan tersebut akan dipindahkan ke TPS kontainer yang disediakan di depan pasar.

4) Pengangkutan

Kegiatan pengangkutan sampah dilakukan oleh petugas kebersihan dari Dinas Kebersihan Kota Mataram dengan waktu pengangkutan pada pukul 07.00 Wita atau pukul 17.00 Wita. Frekuensi pengangkutan sampah di Pasar Dasan Agung, dilakukan sebanyak 1 kali dalam 2 hari. Sampah yang terkumpul di kontainer, kemudian diangkut ke TPA Kebon Kongok Lombok Barat dengan sistem tercampur untuk semua jenis sampah.

5) Pengolahan dan pemanfaatan kembali

Berdasarkan hasil survey dan wawancara di lokasi penelitian, pengelolaan sampah di Pasar Dasan Agung belum menerapkan kegiatan pengolahan dan pemanfaatan kembali sampah yang dihasilkan. Sampai pada saat ini, pola pengelolaan yang diterapkan hanya sebatas kegiatan pewadahan tercampur, pengumpulan, dan pengangkutan ke TPA.

Pertumbuhan penduduk dan tingkat aktivitas penduduk sangat erat hubungannya dengan peningkatan jumlah timbulan sampah. Oleh karena itu, perlu penerapan pola pengelolaan sampah yang baik meliputi kegiatan reuse, reduce, dan recycle/reprocessing guna mencegah terjadinya pencemaran lingkungan dan memberikan nilai tambah ekonomi untuk meningkatkan kesejahteraan masyarakat [13].

\section{Perencanaan Pengelolaan Sampah Pasar Dasan Agung}

1) Perkiraan Pertumbuhan Jumlah Pedagang

Menurut hasil wawancara dengan pihak pengelola pasar, bahwa sampai pada saat ini belum ada rencana pengembangan pasar, namun tetap ada adalah perbaikan gedung dan fasilitas jika mengalami kerusakan. Sehingga potensi pertambahan jumlah pedagang sangat kecil kemungkinannya karena tidak adanya pengembangan dan penambahan bangunan pasar. Oleh karena itu perencanaan TPS 3R masih mengacu pada data jumlah pedagang pada saat ini.

2) Timbulan Sampah

Dengan tidak adanya potensi penambahan jumlah pedagang, maka peningkatan jumlah timbulan sampah yang signifikan dapat dipastikan tidak ada, walaupun diperkirakan terjadi fluktuatif jumlah timbulan sampah dengan adanya banyaknya pengunjung pasar. Oleh sebab 
itu, timbulan sampah hasil pengukuran peneliti dapat dijadikan acuan untuk mengetahui timbulan sampah di Pasar Dasan Agung yaitu volume sampah perharinya adalah 6,68 liter/hari/pedagang dan berat timbulan sampah per harinya adalah $1,15 \mathrm{~kg} / \mathrm{hari} /$ pedagang. Jika dikalikan dengan jumlah pedagang 405 orang maka diperoleh totatl timbulan sampah perhari adalah sebesar 2.704 liter atau $2,7 \mathrm{~m}^{3} / \mathrm{hari}$, dan total berat sampah menjadi $467 \mathrm{~kg} / \mathrm{hari}$.

3) Pemilahan Sampah

Kegiatan pemilahan sampah dilakukan sejak dari sumber sampah dengan menyediakan tempat sampah berdasarkan jenisnya. Pengelompokkan jenis sampah dapat dikelompokkan menjadi 3 jenis, yaitu sampah organik yang bisa dikomposkan seperti sisa makanan dan dedaunan, sampah anorganik yang memiliki nilai jual, seperti kertas, plastik, kaleng, dan logam. Selanjutnya adalah jenis sampah lainnya yang akan dibuang ke TPA, yaitu sampah residu yang tidak bernilai ekonomis [9].

Berdasarkan hal tersebut, kegiatan pemilahan sampah yang dapat diterapkan di Pasar Dasan Agung adalah meliputi keterlibatan aktif para pedagang untuk menempatkan sampah pada tempat yang sesuai dengan jenis sampah, kemudian kegiatan pemilahan berikutnya dapat dilakukan di unit TPS 3R sebelum dilakukan tindakan selanjutnya terhadap masing-masing jenis sampah. Kebutuhan lahan untuk kegiatan pemilahan sampah di unit TPS 3R diperkirakan seluas $4-6 \mathrm{~m}^{2}$.

4) Perencanaan Sistem Pewadahan

Sistem pewadahan dengan metode $3 \mathrm{R}$ adalah menciptakan pewadahan terpilah berdasarkan jenis sampah. Dalam perencanaan ini minimal peawadah dengan jenis sampah organic dan anorganik. Dengan demikian, masing-masing pedagang harus memiliki pewadahan terpilah antara sampah organik dan anorganik, oleh karena itu masing-masing pedagang memiliki 2 tong sampah dari total pedagang sebanyak 405 orang. Sehingga total pewadahan yang dibutuhkan adalah sebanyak 810 pewadahan.

Untuk menentukan besaran kapasitas pewadahan yang dibutuhkan, maka dapat mengacu kepada data komposisi sampah yang diperoleh pada saat penelitian. Dimana diperoleh komposisi volume sampah adalah $54,27 \%$ sampah organik dan $45,73 \%$ sampah anorganik. Untuk mengetahui timbulan sampah berdasarkan jenis sampah dan kapasitas pewadahan yang diperlukan, dapat ditunjukkan pada perhitungan berikut ini:

- Volume Timbulan sampah : 6,68 liter/pedagang/hari

- Komposisi sampah :

- Organik : 54,27\%

- Anorganik : 45,73\%

Sehingga,

- Volume sampah organik : $6,68 \times 54,27 \%=3,63$ liter/pedagang/hari

- Volume sampah anorganik : 6,68 x 45,73\% =3,05 liter/pedagang/hari

Berdasarkan perhitungan diatas, kapasitas pewadahan sampah organic dan organik yang disediakan oleh masing-masing pedagang adalah berkisar 4 liter sampai dengan 10 liter yang harus disediakan untuk menampung sampah selama satu hari.

5) Perencanaan Sistem Pengumpulan

Pengumpulan yang dapat diterapkan di pasar Dasan Agung adalah dilakukan setiap hari dan dilakukan setiap sore hari, karena pasar aktif beroperasi pada waktu pagi sampai siang hari. Sehingga pada sore hari petugas kebersihan dapat melaksanakan tugas kebersihannya.

Proses pengumpulan yang dilakukan dengan sistem 3R, yaitu dilakukan pengumpulan terpilah antara sampah organik dan anorganik [14]. Sampah anorganik dapat ambil dan dibawa ke TPS 3R yang disediakan, sedangkan sampah organik dapat dibawa langsung ke unit pengomposan. Proses pengumpulan dilakukan penambahan tenaga 1 orang, sehingga jumlah petugas kebersihan menjadi 6 orang. Pekerjaan pengumpulan menggunakan troli dengan kapasitas 240 liter. Pemilihan troli sebagai alat pengumpulan karena jalur yang dilewati cukup sempit. Perhitungan sistem pengumpulan adalah sebagai berikut:

- Jumlah pedagang : 405 pedagang

- Jumlah petugas kebersihan : 6 orang

- Kapasitas troli : 240 liter

- Volume sampah : 6,68 liter/pedagang/hari 
- Volume sampah organik : 3,62 liter/pedagang/hari

- Volume sampah anorganik : 3,05 liter/pedagang/hari

- Total volume sampah : 405 x 6,68 = 2.704 liter/hari

- Total volume sampah organik : 405 x 3,62 = 1.466 liter/hari

- Total volume sampah anorganik : $405 \times 3,05=1.235$ liter/hari

- Jumlah ritasi pengumpulan sampah organik : $1.466: 240=6,11 \approx 6$ kali

- Jumlah ritasi pengumpulan sampah anorganik : $1.235: 240=5,15 \approx 6$ kali

Berdasarkan hasil perhitungan diatas, diketahui untuk sistem pengumpulan adalah dilakukan oleh 6 orang tenaga kebersihan, sehingga masing-masing tenaga melakukan pengumpulan sebanyak 1 kali ritasi setiap harinya.

6) Perencanaan Sistem Pengangkutan

Proses pengangkutan yang direncanakan adalah mengangkut sampah residu untuk dibuang ke TPA. Sampah residu ini adalah sampah yang tidak dapat diolah atau dijual oleh pihak pengelola sampah, sehingga diperkirakan jumlah sampah yang diangkut akan berkurang dari total timbulan sampah yang dihasilkan di pasar Dasan Agung dan dilakukan setiap hari sekitar pukul 17.00 Wita.

Pengangkutan lain yang dilakukan adalah pengangkutan sampah organik hasil pemilahan dan bernilai ekonomis. Namun, dapat diperkirakan pengangkutan ini dilakukan secara periodik (tergantung banyaknya sampah yang dijual) dan dilakukan oleh pihak pembeli.

Pengangkutan sampah residu untuk dibuang ke TPA diasumsikan sebesar 20\% dari total timbulan sampah yang ada di pasar. Perhitungan sistem pengangkutan sampah Pasar Dasan Agung ke TPA adalah sebagai berikut:

- Asumsi sampah residu : $20 \%$

- Total volume timbulan sampah : 2704 liter/hari, setara $2,7 \mathrm{~m}^{3} /$ hari

- Kapasitas truk sampah : $6 \mathrm{~m}^{3}$

- Total sampah residu : $20 \%$ x $2.704=540,80$ liter/hari, atau $0,5 \mathrm{~m}^{3} /$ hari

- Lama waktu setiap satu kali pengangkutan $=6 \mathrm{~m}^{3}: 0,5 \mathrm{~m}^{3}=11$ hari

Berdasarkan hasil perhitungan di atas, dapat diketahui total sampah residu yang dibuang ke TPA sebanyak $0,5 \mathrm{~m}^{3} /$ hari. Jika menggunakan truk sampah dengan kapasitas $6 \mathrm{~m}^{3}$, maka dapat dilakukan penumpukan sampah selama 11 hari untuk mendapatkan total sampah $6 \mathrm{~m}^{3}$ yang dibawa ke TPA. Namun perlu dipertimbangkan faktor pencemaran terhadap lingkungan yang diakibatkan oleh penumpukkan sampah, sehingga dapat ditentukan pengangkutan sampah maksimal dilakukan selama 3 hari untuk satu kali pengangkutan. Oleh karena itu, total sampah yang harus diangkut pada setiap kali pengangkutan adalah sebesar $1,5 \mathrm{~m}^{3}$.

7) Perencanaan Unit Pengomposan

Metode pengomposan yang dipilih adalah menggunakan drum dan bantuan bioaktivator berupa mikro organisme lokal (MOL). Penggunaan MOL sebagai bioaktivator mampu mempercepat proses pengomposan yang berkisar $14-21$ hari [15]. Perhitungan rencana kebutuhan unit pengomposan dengan sistem komposter drum mengacu pada petunjuk teknik TPS 3R [16]. Adapun rencana kebutuhan unit pengomposan adalah dapat ditunjukkan pada Tabel 5.

Tabel 5. Rencana kebutuhan unit pengomposan

\begin{tabular}{|c|c|c|}
\hline Uraian & Jumlah & Satuan \\
\hline \multicolumn{3}{|l|}{ Dimensi Komposter Drum } \\
\hline Diameter drum & 0,5 & $\mathrm{~m}$ \\
\hline Panjang drum & 1 & $\mathrm{~m}$ \\
\hline Panjang total rotary drum & 1,3 & $\mathrm{~m}$ \\
\hline \multicolumn{3}{|l|}{ Total Volume Pengomposan } \\
\hline Jumlah layanan & 405 & pedagang \\
\hline Timbulan sampah hasil sampling (liter) & 6,68 & lt/pedagang/hari \\
\hline Timbulan sampah hasil sampling $\left(\mathrm{m}^{3}\right)$ & 0,01 & $\mathrm{~m}^{3} /$ pedagang/hari \\
\hline Total timbulan sampah (liter) & 2704,05 & lt/hari \\
\hline Total timbulan sampah $\left(\mathrm{m}^{3}\right)$ & 2,70 & $\mathrm{~m} 3 /$ hari \\
\hline$\%$ sampah organik & 54,27 & $\%$ \\
\hline Volume sampah organik (liter) & 1467,45 & lt/hari \\
\hline Volume sampah organik $\left(\mathrm{m}^{3}\right)$ & 1,47 & $\mathrm{~m}^{3} /$ hari \\
\hline Densitas & 190,16 & $\mathrm{Kg} / \mathrm{m}^{3}$ \\
\hline Berat Timbulan Sampah & 1,27 & $\mathrm{Kg} / \mathrm{m}^{3}$ \\
\hline Waktu Pengomposan & 21 & hari \\
\hline Total Volume Pengomposan : lama pengomposan $\times$ volume sampah per hari & 30,82 & $\mathrm{~m}^{3} /$ hari \\
\hline
\end{tabular}




\begin{tabular}{|c|c|c|}
\hline Uraian & Jumlah & Satuan \\
\hline \multicolumn{3}{|c|}{ Penentuan Volume Tiap Komposter Drum } \\
\hline $\begin{array}{l}\text { Volume setiap Rotary Drum } \\
3,14 \times(0,2) 2 \times 0,8=0,10048 \mathrm{~m}^{3}\end{array}$ & $\begin{array}{l}\pi \times r^{2} \times \\
\text { tinggi } \\
0,10048 \\
100,48\end{array}$ & $\begin{array}{c}\mathrm{m}^{3} \\
\text { liter }\end{array}$ \\
\hline \multicolumn{3}{|c|}{ Jumlah kebutuhan Komposter Drum } \\
\hline jumlah kebutuhan & 307 & buah \\
\hline \multicolumn{3}{|c|}{ Penentuan Luas Kebutuhan Ruang } \\
\hline Space antara pada ujung drum & 0,2 & $\mathrm{~m}$ \\
\hline Panjang per unit drum & 0,4 & $\mathrm{~m}$ \\
\hline Lebar per unit kompos $=$ lebar rotary drum + space ujung A & 0,6 & $\mathrm{~m}$ \\
\hline Ruang untuk satu unit drum $=$ panjang $\times$ lebar & 0,24 & $\mathrm{~m}$ \\
\hline Kebutuhan ruang total $=$ Jumlah Komposter Drum $\times$ ruang untuk 1 unit & 74 & $\mathrm{~m}^{2}$ \\
\hline
\end{tabular}

Sumber: Hasil analisa, 2019

Berdasarkan hasil analisis kebutuhan unit pengomposan tersebut, diketahui kebutuhan lahan untuk pengomposan metode drum adalah seluas $74 \mathrm{~m}^{2}$ dengan banyaknya unit komposter sebanyak 307 buah, dengan perkiraan lama waktu pengomposan masing-masing unit komposter adalah selama 21 hari.

8) Kegiatan Reduce dan Reuse di Pasar Dasan Agung

Pengurangan sampah (Reduce) di TPS 3R Pasar Dasan Agung diperoleh dari banyak sampah yang dapat didaur ulang di TPS 3R dan banyak sampah yang akan dibuang ke TPA Kebon Kongok. Adapun sampah yang dapat didaur ulang di TPS 3R ialah sampah organik sebesar 1,5 $\mathrm{m}^{3} /$ hari yang menjadi kompos dan sampah anorganik dapat dijual atau dimanfaatkan menjadi barang bernilai ekonomis sebesar $1,3 \mathrm{~m}^{3} /$ hari. Sampah yang akan dibuang ke TPA Kebon Kongok adalah sampah residu yang diperkirakan sekitar $20 \%$ dari total timbulan sampah. Dengan perhitungan persentase, maka persentase pengurangan sampah di TPS $3 \mathrm{R}$ di Pasar Dasan Agung adalah sebesar 80\%.

Pemakaian sampah kembali (Reuse) di TPS 3R Pasar Dasan Agung dilakukan melalui pemilahan benda-benda yang dapat digunakan kembali seperti kertas, plastik, kaleng, botol, kaca dan bahan metal lainnya. Pemilahan lebih ditujukan di setiap pedagang melalui sosialisasi yang akan dilakukan oleh petugas pasar. Maka pengurangan sampah (reduce) dengan cara pemakaian kembali (reuse) juga terjadi di sumber sampah. Walaupun demikian, kegiatan pemilahan sampah di unit TPS 3R tetap dilakukan.

9) Bangunan TPS $3 R$

Penerapan metode TPS 3R dalam penanganan sampah dapat mengurangin total timbulan sampah yang dibuang ke TPA sebesar 22,40\% [17]. Pada penelitian ini, merencanakan penanganan sampah dengan asumsi sampah terolah sebesar $80 \%$ dan sampah residu sebesar $20 \%$.

Bangunan TPS 3R yang direncanakan adalah untuk dapat menampung sampah anorganik yang dihasilkan setiap harinya yaitu sebesar $3,05 \mathrm{~m}^{3} /$ hari. Diperkirakan kebutuhan luas lahan yang harus disedikan untuk menampung sampah anorganik jika lama waktu menampung selama 1 minggu $\left(21,38 \mathrm{~m}^{3} / \mathrm{minggu}\right)$ adalah seluas $11 \mathrm{~m}^{2}$ dengan ketinggian penumpukan 2-3 meter. Kemudian kebutuhan luas lahan untuk keperluan lain juga perlu disediakan sehingga perkiraan kebutuhan luas lahan seluruhnya adalah 6 meter x 6 meter $=36 \mathrm{~m}^{2}$.

Dengan perkiraan jumlah kebutuhan luas lahan tersebut, dapat ditentukan lokasi TPS 3R di Pasar Dasan Agung adalah berlokasi di tempat TPS sebelumnya namun perlu pembangunan dengan konstruksi yang baik dan memiliki nilai estetika tentunya.

Rencana penataan dan lokasi TPS 3R serta unit pengomposan di Pasar Dasan Agung dapat dilihat pada Gambar 3 dan Gambar 4. 

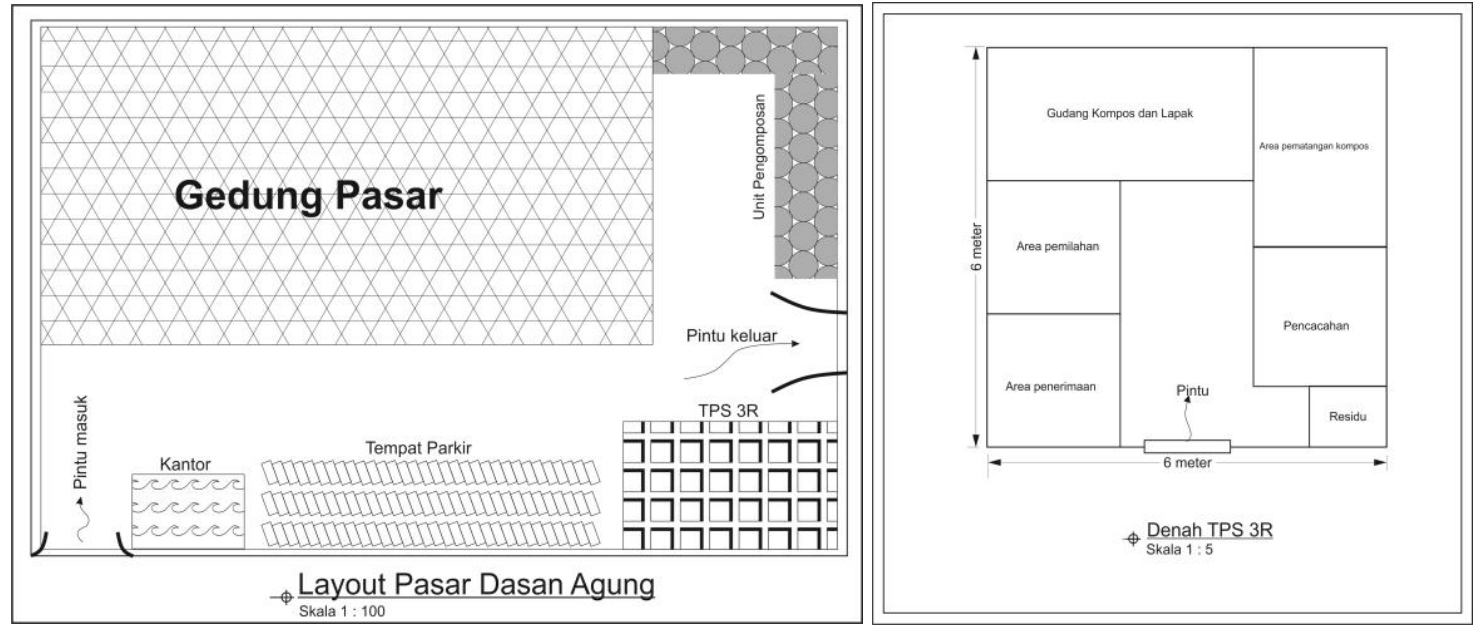

Gambar 3. Layout perencanaan TPS3R di Pasar Dasan Agung Kota Mataram

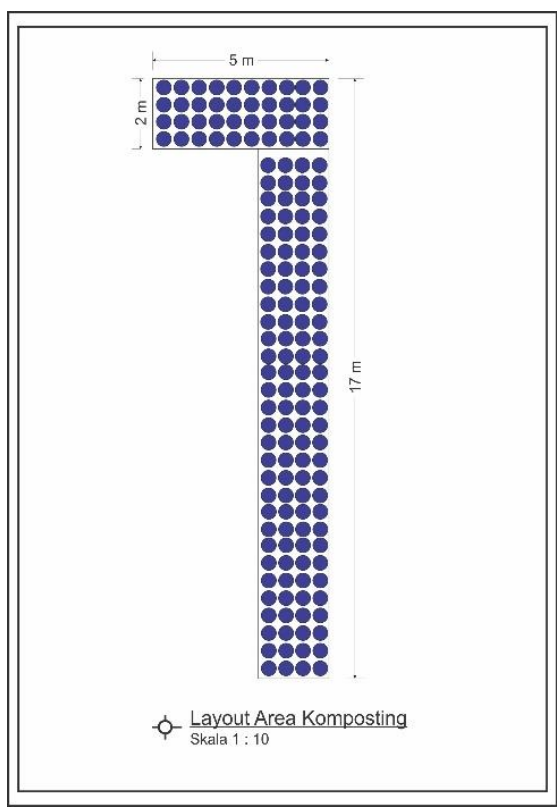

(a)

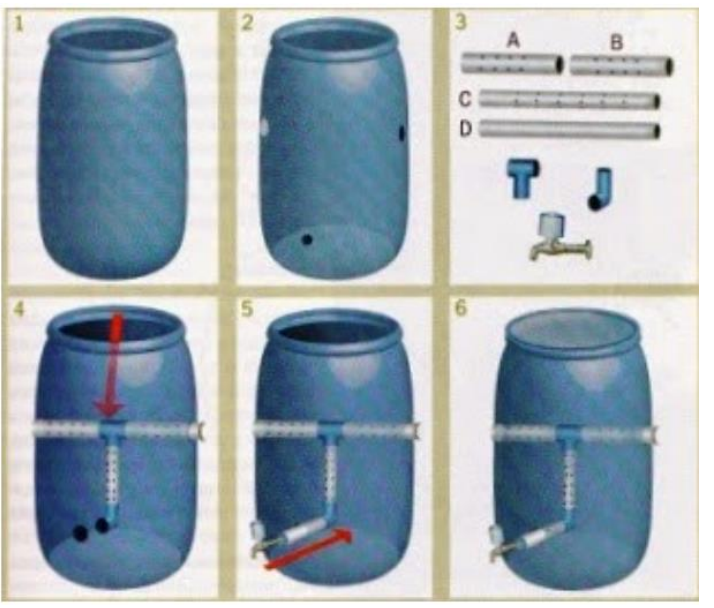

(b)

Gambar 4. (a) Layout unit pengomposan dan (b) Desain komposter Sumber gambar (b): [16]

\section{Kesimpulan}

Berdasarkan hasil penelitian dan perencanaan, peneliti dapat menarik kesimpulan antara lain sebagai berikut:

a. Timbulan sampah di Pasar Dasan Agung, dengan volume sampah sebesar 2,7 $\mathrm{m}^{3} /$ hari dan berat sampah sebesar $467 \mathrm{~kg} / \mathrm{hari}$.

b. Komposisi sampah berdasarkan satuan volume yaitu sampah organik 54,27\% dan sampah anorganik sebanyak $45,73 \%$. Sedangkan berdasarkan satuan berat yaitu komposisi sampah organik sebanyak $52,60 \%$ dan sampah anorganik sebanyak $47,40 \%$.

c. Hasil perencanaan TPS 3R mempunyai spesifikasi sebagai berikut:

1) Luas lahan TPS $3 R$ dibutuhkan minimal seluas $110 \mathrm{~m}^{2}$, untuk menampung sampah anorganik sebanyak $2,7 \mathrm{~m}^{3} /$ hari, dan unit pengomposan akan menampung sampah organik untuk dikomposkan sebanyak $1,5 \mathrm{~m}^{3} /$ hari.

2) Pengomposan sampah organik menggunakan metode drum kapasitas $100 \mathrm{lt}$, kebutuhan drum sebanyak 307 buah dengan kebutuhan luas lahan seluas $74 \mathrm{~m}^{2}$.

3) Sistem pewadahan yang direncanakan yaitu secara terpisah sampah organik dan anorganik, dengan kapasitas 10 liter.

4) Sistem pengumpulan dilakukan setiap hari dengan menggunakan troli 240 liter dan tenaga pekerja sebanyak 6 orang, frekuensi pengumpulan dilakukan sebanyak 1 kali per hari. 
5) Sistem pengangkutan dapat dilakukan setiap 3 hari sekali dengan total sampah residu yang dibuang sebanyak $1,5 \mathrm{~m}^{3}$.

\section{Daftar Pustaka}

[1] H. Sulistyo and B. Cahyono, "Model Pengembangan Pasar Tradisional Menuju Pasar Sehat di Kota Semarang," Jurnal Ekonomi dan Bisnis, vol. 11, no. 2, pp. 516-526, Juli 2010.

[2] Anonim, "Undang-Undang Republik Indonesia No. 18 Tahun 2008 Tentang Pengelolaan Sampah," Menteri Hukum dan Hak Asasi Manusia Republik Indonesia, Jakarta, 2008.

[3] M. Tarigan, A. Setiawan and I. S. Sideman, "Perencanaan TPS 3R di Kelurahan Dayan Peken," Jurusan Teknik Sipil, Fakultas Teknik, Universitas Mataram, Mataram, 2016.

[4] E. Siswandi and Wahyudin, "Pemetaan Tempat Penampungan Sampah (TPS) Ilegal Menggunakan Geograpich Information System (GIS) di Wilayah Kecamatan Mataram Kota Mataram," Jurnal Ilmiah MITSU, vol. 7, no. 2, pp. 8-16, 24 Oktober 2019.

[5] D. Kasih, I. Indrawan, L. Setyowati, M. Tanjung and I. Suryati, "Studi Perancangan Dan Pemanfaatan TPS 3R Untuk Sampah TPS (Tempat Pengolahan Sampah) Rumah Tangga," Jurnal Dampak, vol. 15, no. 1, pp. 16-22, 2018.

[6] Y. Ruslinda and V. , "Satuan Timbulan dan Komposisi Sampah Industri Kota Padang," Jurnal Dampak, vol. 10, no. 1, pp. 20-28, 012013.

[7] N. Azmiyah, R. Purnaini and M. Indrayadi, "Perencanaan Sistem Pengelolaan Sampah Terpadu di Kawasan Pasar Flamboyan Kota Pontianak," Jurnal Teknologi Lingkungan Lahan Basah, vol. 2, no. 1, pp. 1-10, 2014.

[8] Wahyudin and H. Susane, "Studi Sistem Pengelolaan Sampah Pasar di Pasar Tradisional Pagesangan Kota Mataram," Jurnal Akrab Juara, vol. 3, no. 2, pp. 46-55, Mei 2018.

[9] S. Raharjo, M. Zulfan, T. Ihsan and Y. Ruslinda, "Perencanaan Sistem Reduce, Reuse, dan Recycle Pengelolaan Sampah di Kampus Universitas Andalas Limau Manis Padang," Jurnal Dampak, vol. 11, no. 2, pp. 79-87, Juli 2014.

[10] Dinas Perdagangan Kota Mataram, "Profil Pasar Rakyat Mataram," Dinas Perdagangan, Kota Mataram, 2017.

[11] Badan Standarisasi Nasional, SNI 19-3964-1994 Metode pengambilan dan pengukuran contoh timbulan dan komposisi sampah perkotaan, Jakarta: Badan Standarisasi Nasional, 1994.

[12] Badan Standarisasi Nasional, SNI 19-2454-2002 Tata Cara Teknik Operasional Pengelolaan Sampah Perkotaan, Jakarta: Badan Standarisasi Nasional, 2002.

[13] S. Yana and Badaruddin, "Pengelolaan Limbah Plastik Sebagai Upaya Pengurangan Pencemaran Lingkungan Melalui Transformasi Yang Memiliki Nilai Tambah Ekonomi," Serambi Engineering, vol. II, no. 4, pp. 157-164, Agustus 2017.

[14] J. R. Rumasondi, I. B. Priyambada and D. S. Handayani, "Perencanaan sistem Pengelolaan Sampah Terpadu Studi Kasus RW 1, 2, dan 12 Kelurahan Bandarharjo Kecamatan Semarang Utara Kota Semarang," Jurnal Teknik Lingkungan, vol. 6, no. 1, pp. 1-12, 2017.

[15] Wahyudin and Nurhidayatullah, "Pengomposan Sampah Organik Rumah Tangga Menggunakan Mikroorganisme Lokal Bonggol Pisang Sebagai Bioaktivator," Jurnal Agriovet, vol. 1, no. 1, pp. 1936, Oktober 2018.

[16] Kementerian Pekerjaan Umum dan Perumahan Rakyat, Petunjuk Teknis Perencanaan Tempat Pengolahan Sampah 3R, Jakarta: Kementerian Pekerjaan Umum dan Perumahan Rakyat, Direktorat Jenderal Cipta Karya, 2017.

[17] R. Aziz, T. Ihsan and A. S. Permadani, "Skenario Pengembangan Sistem Pengelolaan Sampah Kabupaten Pasaman Barat dengan Pendekatan Skala Pengolahan Sampah di Tingkat Kawasan dan Kota," Serambi Engineering, vol. IV, no. 1, pp. 444-450, April 2019. 